\title{
Kinerja Guru PAUD Di Kota Serang pada Masa Pandemi Covid 19
}

\author{
Reza Mauldy Raharja1, Rr. Dina Kusuma Wardhani², Laily Rosidah $^{3}$
}

Pendidikan Guru Pendidikan Anak Usia Dini, FKIP, UNTIRTA

e-mail: reza.mauldy@untirta.ac.id¹, dinakusuma_wardhani@untirta.ac.id², laily@untirta.ac.id³,

\begin{abstract}
ABSTRAK. Penelitian ini bertujuan untuk mengetahui kinerja guru paud di kota serang pada dimensi kompetensi paedagogik, dimana pada masa pandemic covid 19 apakah guru melakukan proses pembelajaran dirumah sehingga anak mengalami proses belajar di rumah dengan pendampingan orang tua. Metode penelitian yang digunakan dalam penelitian ini adalah mixed method, dengan menggabungkan dua bentuk penelitian yang telah ada sebelumnya yaitu kualitatif dan kuantitatif. Hasil yang diperoleh dalam penelitan ini, secara keseluruhan kinerja guru paud pada dimensi kompetensi paedagogik berada pada kategori sangat baik, hal ini didasarkan pada hasil perhitungan dengan menggunakan WMS (Weigh Mean Score) berada pada angka 4,34 artinya jka dikonversi pada table kosnultasi dengan skor maskimal 5.00 kinerja guru paud di kota serang pada masa pandemic covid 19 ini sangat baik.
\end{abstract}

Kata Kunci : Covid-19, Kinerja Guru, Kompetensi Guru.

ABSTRACT. This aims to describe to see the performance of PAUD teachers in the city of Serang on the pedagogical competency dimension, where during the Covid19 pandemic did the teacher carry out the learning process at home so that the child experienced the learning process at home with the parens as a assistance. The research method used in this research is mixed method, by combining two pre-exixting forms of research, namely qualitative and quantitative. The result obtained in this study, the overall performancar of paud teachers in the pedagogical competency dimension is in the very good category, this is based on the result of calculation using the WMS (Weigh Mean Score) which is at 4.34, which is if on the consultation table with a maximum score 5.00 The performance of PAUD teacher in the City of Serang during the Covid19 pandemic was very good.

Keyword : Covid-19, Teacher Performance, Teacher Competence. 


\section{PENDAHULUAN}

Indonesia mengalami peristiwa yang dialami oleh seluruh dunia yaitu pandemi covid 19. Pandemi covid 19 membuat pemerintah mengeluarkan pernyataan bahwa masa Pandemi covid 19 adalah masa darurat yang akhirnya memunculkan kebijakankebijakan dibawahnya salah satunya adalah kebijakan Kemdikbud untuk merumahkan siswa dan diterjemahkan secara teknis oleh dinas-dinas Pendidikan di beberapa wilayah yang dimulai dari DKI Jakarta, Banten dan Jawa Barat. Pembatasan Sosial Berskala Besar untuk beberapa Kabupaten Kota di Banten dan di Indonesia. Kebijakan PSBB sebagaimana dimaksud sesuai Peraturan Gubernur Nomor 16 dan 18 tahun 2020 tentang Penetapan Pembatasan Sosial Berskala Besar di Wilayah Kabupaten Tangerang, Kota Tangerang dan Kota Tangerang Selatan Dalam Rangka Percepatan Penanganan Corona Virus Disease 2019 (COVID-19) tertanggal 15 April 2020, serta Peraturan Gubernur Banten Nomor 16 Tahun 2020 tentang Pedoman Pelaksanaan Pembatasan Sosial Berskala Besar Dalam Penanganan Corona Virus Disease 2019 (Covid-19) Di Kabupaten Tangerang, Kota Tangerang dan Kota Tangerang Selatan tertanggal 15 April 2020 yang kemudian direvisi menjadi Pergub nomor 18 tahun 2020 dan Keputusan Gubernur nomor 443/Kep.140-Huk/2020 tentang Penetapan Pembatasan Sosial Berskala Besar di Wilayah Kabupaten Tangerang, Kota Tangerang dan Kota Tangerang Selatan Dalam Rangka Percepatan Penanganan Corona Virus Disease 2019 (COVID-19) tertanggal 15 April 2020[1].

Semua Sekolah mengganti proses pembelajaran dengan belajar di rumah dengan masing-masing memiliki atau menggunakan flatform berbeda-beda begitupun juga penamaannya. Beberapa sekolah memberi nama prosesnya sebagai Learning From Home, E-Learning, Learning Base Home yang semuanya penamaan dan teknik yang berbeda untuk masing-masing sekolah. Persamaan dari semua proses belajar di rumah adalah semuanya menggunakan sistem Daring. Beberapa aplikasi digunakan oleh masing-masing sekolah dalam usaha memperlancar proses pembelajaran tersebut. Masa ini menjadikan sistem daring menjadi hal yang tidak lagi aneh karena semua sekolah menggunakannya. Semua guru dan orang tua siswa mengalami penguasaan baru yaitu teknologi yang digunakan untuk belajar jarak jauh. Proses belajar dirumah menggunakan teknologi menjadi keahlian yang harus dimiliki oleh semua guru di setiap sekolah karena menunjang kelancaran dan proses belajar yang berkelanjutan. Keahlian 
yang sebelumnya mungkin tidak dikuasai oleh beberapa guru tetapi sekarang harus belajar mengikuti teknologi yang ada demi kelancaran semua proses pembelajaran.

Kinerja juga merupakan suatu kegiatan yang dilakukan untuk melaksanakan, menyelesaikan tugas dan tanggung jawab sesuai dengan harapan dan tujuan yang telah ditetapkan[2]. Kinerja guru dalam pembelajaran jarak jauh dengan memanfaatkan teknologi merupakan bagian yang penting dalam menunjang proses pembelajaran. Guru bisa memilih menggunakan aplikasi yang paling dikuasainya ataupun guru dapat meluangkan waktu lebih untuk mempelajari aplikasi baru agar bisa berkomunikasi atau bahkan mengevaluasi apakah materi sudah tersampaikan dengan baik. Jenis jenis aplikasi yang banyak digunakan antara lain adalah zoom meet, google drive, email, whatsapp dan masih banyak lagi. Hasil penelitian yang dilakukan Pudyastuti menunjukkan bahwa sebanyak 75\% orang guru memilih untuk menggunakan platform WhatsApp dalam menjalankan proses pembelajaran e-learning[3]. Aktivitas lain yang mereka kerjakan adalah bermain handphone. Mereka mengatakan selama WFH ini, mereka tidak bisa menahan diri bermain handphone karena dalam mengerjakan tugas mereka menggunakan handphone[4]. Bentuk-bentuk aplikasi yang digunakan dalam pembelajaran online adalah Whatsapp Group, Zoom, dan E-mail[5].

Dalam memberikan materi guru dibantu orang tua untuk menyiapkan perangkat teknologi tersebut, karena usia PAUD merupakan usia anak yang masih memerlukan pendampingan dalam menggunakan gawai. Anak bisa mengerjakan terlebih dahulu dalam lembar kerjanya dilanjutkan pelaporan melalui aplikasi yang ditentukan oleh guru. peran orang tua dalam pendidikan anak usia dini dapat disimpulkan orang tua mengkondisikan lingkungan keluarga dengan menjadikan rumah sebagai tempat yang nyman untuk menunjang pendidikan anak[6]. Hasil penelitian Diah menyimpulkan bahwa menghadapi situasi pembelajaran di rumah, ibu merasa bingung untuk bermain bersama anaknya. Ibu juga merasakan lelah, bosan, dan kurang sabar, karena banyaknya pekerjaan lain yang harus dilakukan ibu selain mengurus anak. Kurangnya kesiapan ibu untuk bermain bersama anak sepanjang hari dan setiap hari selama masa PSBB[7].

Kegiatan belajar di rumah diberikan dengan berpijak pada prinsip pembelajarn AUD yang berpusat pada proses bukan terhadap hasil. Pijakan tersebut menjadikan guru dengan kreatifitasnya memberikan kegiatan yang dapat membahagiakan anak dan tidak memberatkan orang tua. Inilah yang menjadi tantangan guru di masa covid 19 karena 
guru dituntut kreatif dalam menciptakan kegiatan belajar untuk anak didik di rumah dengan bimbingan orang tua masing-masing.

\section{METODE}

Untuk mengetahui kinerja guru paud pada masa pandemic covid 19 ini peneliti menggunakna metode gabungan (mixed method) yatu penelitian kualitatif dan penelitian kuantitatif. Penelitian ini dilakukan di lembaga PAUD yang beraada di Kota serang Provinsi Banten, sementara itu populasi penelitian ini adalah kepala sekolah dan guru di lembaga PAUD dengan menggunakan purposive random sampling. Data angket yang diberikan pada Kepala sekolah kemudian diolah secara objektif dan kemudian dianalisis secara deskriptif. Hasilnya digunakan untuk menemukan informasi terkait kinerja guru PAUD pada masa pandemi covid 19 ini karena sampai dengan saat ini belum ada kepastian kapan wabah ini akan berakhir. Adapun tahap penganalisaan data angket adalah (1) data angket diperiksa dan diklarifikasikan secara objektif, (2) data angket dianalisis serta dideskripsikan, dan (3) ditarik kesimpulan. Analisis data untuk mengetahui kinerja guru paud di kota serang pada masa pandemic covid 19 dengan mencari skor rata-rata (WMS), angka presentase variabel ini dihitung dengan menggunakan rumus berikut:

$$
\bar{X}=\frac{X}{N}
$$

\section{Keterangan :}

$\bar{X} \quad=$ Nilai rata-rata yang dicari

$\mathrm{X}=$ Jumlah skor gabungan (frekuensi jawaban dikali bobot untuk setiap alternatif kategori)

$\mathrm{N}=$ Jumlah Responden

Untuk menentukan kriteria pengelompokkan WMS untuk skor rata-rata setiap kemungkinan jawaban. Kriterianya sebagai berikut:

Tabel 1 Konsultasi WMS

\begin{tabular}{ccc}
\hline Rentang Nilai & Kriteria & Penafsiran \\
\cline { 3 - 3 } & & Kinerja mengajar Guru PAUD \\
\hline $\mathbf{4 , 0 1 - 5 , 0 0}$ & Sangat Baik & Selalu \\
\hline $\mathbf{3 , 0 1 - 4 , 0 0}$ & Baik & Sangat Sering \\
\hline $\mathbf{2 , 0 1 - 3 , 0 0}$ & Cukup & Sering \\
\hline $\mathbf{1 , 0 1 - 2 , 0 0}$ & Rendah & Jarang \\
\hline $\mathbf{0 , 0 1 - 1 , 0 0}$ & Sangat Rendah & Tidak Pernah \\
\hline
\end{tabular}

Sesuai dengan karakteristik metode kombinasi, dimana pada tahap pertama penelitian menggunakan metode kuantitatif dan pada tahap berikutnya menggunajanmetode kualitatif. Penekanan metode lebih pada metode pertama yaitu kuantitatif dan selanutnya dilengkapi penekanan metode kualitatif Pencampuran kedua metode tersebut bersifat connecting (menyambung) antara hasil penelitian pertama dan 
tahap berikutnya. Berdasarkan uraian tersebut, maka desain penelitian yang akan peneliti gunakan adalah sebagai berikut:

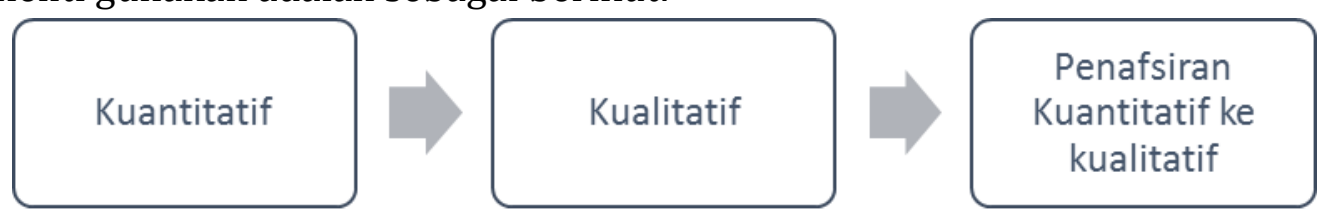

\section{HASIL DAN PEMBAHASAN}

Kegiatan ini merupakan pemberian skor pada setiap alternatif jawaban yang diberikan oleh responden sesuai dengan bobot yang telah ditetapkan. Setiap pernyataan dalam ketiga variabel memiliki 5 kriteria jawaban dengan pemberian skor dimulai dari 1,2,3,4 dan 5 dengan ketentuan untuk pernyataan yang dihitung dengan hasil perhitungan deskriptif. Perhitungan angka presentase dari setiap variabel bertujuan untuk mengetahui kecenderungan umum jawaban responden. Untuk memperoleh gambaran mengenai kecenderungan umum skor responden pada kinerja mengajar guru PAUD di kota Serang pada masa pandemi Covid 19, maka hasil perhitungannya diuaraikan berikut ini:

Tabel 2.

Kecendrungan Skor Rata-rata Kinerja Mengajar Guru di Kota Serang

\begin{tabular}{|c|c|c|c|c|}
\hline Variabel & Indikator & Item & Mean & Kategori \\
\hline \multirow{17}{*}{$\begin{array}{l}\text { Kinerja } \\
\text { Mengajar } \\
\text { Guru PAUD }\end{array}$} & \multirow{3}{*}{$\begin{array}{l}\text { Mengorganisasikan aspek } \\
\text { perkembangan sesuai dengan } \\
\text { karakter anak usia dini }\end{array}$} & 1 & 4.35 & Sangat Baik \\
\hline & & 2 & 4.32 & Sangat Baik \\
\hline & & 3 & 4.19 & Sangat Baik \\
\hline & \multicolumn{2}{|l|}{ Rata-rata } & 4.28 & Sangat Baik \\
\hline & \multirow{3}{*}{ Menganalisis Teori Bermain } & 4 & 4.21 & Sangat Baik \\
\hline & & 5 & 4.48 & Sangat Baik \\
\hline & & 6 & 4.40 & Sangat Baik \\
\hline & \multicolumn{2}{|l|}{ Rata-rata } & 4.36 & Sangat Baik \\
\hline & \multirow{2}{*}{$\begin{array}{l}\text { Merancang Kegiatan } \\
\text { Pengembangan AUD Berdasar } \\
\text { Kurikulum }\end{array}$} & 7 & 4.64 & Sangat Baik \\
\hline & & 8 & 4.48 & Sangat Baik \\
\hline & \multicolumn{2}{|l|}{ Rata-rata } & 4.56 & Sangat Baik \\
\hline & \multirow{2}{*}{$\begin{array}{l}\text { Menyelenggarakan Kegiatan } \\
\text { Pengembangan yang mendidik }\end{array}$} & 9 & 4.35 & Sangat Baik \\
\hline & & 10 & 4.08 & Sangat Baik \\
\hline & \multicolumn{2}{|l|}{ Rata-rata } & 4.21 & Sangat Baik \\
\hline & \multirow{2}{*}{$\begin{array}{l}\text { Memanfaatkan TIK untuk } \\
\text { Kepentingan penyelenggaraan } \\
\text { pengembangan yang mendidik }\end{array}$} & 11 & 4.07 & Sangat Baik \\
\hline & & 12 & 3.97 & Baik \\
\hline & Rata-rata & & 4.02 & Sangat Baik \\
\hline
\end{tabular}




\begin{tabular}{|c|c|c|c|}
\hline Mengembangkan potensi AUD & 13 & 4.21 & Sangat Baik \\
\hline Untuk Pengaktualisasian diri & 14 & 4.52 & Sangat Baik \\
\hline \multicolumn{2}{|l|}{ Rata-rata } & 4.37 & Sangat Baik \\
\hline \multirow{2}{*}{$\begin{array}{l}\text { Berkomunikasi Secara Efektif, } \\
\text { Simpatik dan Santun }\end{array}$} & 15 & 4.49 & Sangat Baik \\
\hline & 16 & 4.60 & Sangat Baik \\
\hline \multicolumn{2}{|l|}{ Rata-rata } & 4.55 & Sangat Baik \\
\hline $\begin{array}{l}\text { Guru membuat laporan } \\
\text { penilaian dan evaluasi proses } \\
\text { hasil belajar anak saat BDR }\end{array}$ & 17 & 4.45 & Sangat Baik \\
\hline \multicolumn{2}{|l|}{ Rata-rata } & 4.45 & Sangat Baik \\
\hline \multirow{4}{*}{$\begin{array}{l}\text { Menentukan lingkup sasaran } \\
\text { asesmen proses dan hasil } \\
\text { pembelajaran pada AUD }\end{array}$} & 18 & 4.69 & Sangat Baik \\
\hline & 19 & 4.32 & Sangat Baik \\
\hline & 20 & 4.65 & Sangat Baik \\
\hline & 21 & 4.63 & Sangat Baik \\
\hline \multicolumn{2}{|l|}{ Rata-rata } & 4.57 & Sangat Baik \\
\hline \multirow{2}{*}{$\begin{array}{l}\text { Menggunakan hasil penialian, } \\
\text { pengembangan dan evaluasi } \\
\text { program untuk kepentingan } \\
\text { pengembangan AUD }\end{array}$} & 22 & 4.44 & Sangat Baik \\
\hline & 23 & 4.03 & Sangat Baik \\
\hline \multicolumn{2}{|l|}{ Rata-rata } & 4.23 & Sangat Baik \\
\hline $\begin{array}{l}\text { Melakukan tindakan reflektif, } \\
\text { korektif dan inovatif dalam } \\
\text { meningkatkan kualitas } \\
\text { pembelajaran }\end{array}$ & 24 & 4.15 & Sangat Baik \\
\hline \multicolumn{2}{|l|}{ Rata-rata } & 4.15 & Sangat Baik \\
\hline Rata-rata Keseluruhan & & 4.34 & Sangat Baik \\
\hline
\end{tabular}

Dari tabel di atas dapat dilihat bahwa mengorganisasikan aspek perkembangan sesuai dengan karakter anak usia dini masuk kategori sangat baik. Aspek perkembangan anak usia dini harus menjadi prioritas utama dalam pembelajaran daring di masa pademi covid 19 ini. Menurut Musfirah bahwa aspek yang dikembangkan dalam PAUD adalah aspek pengembangan pembiasaan meliputi sosial, emosi, kemandirian, moral, dan nilai-nilai agama, serta pengembangan kemampuan dasar yang meliputi pengembangan bahasa, kognitif, dan fisik motorik[8]. Dalam Permendikbud nomor 137 Tahun 2014 disebutkan bahwa aspek perkambangan anak usia dini terdiri dari aspek nilai moral dan agama, aspek kognitif, aspek sosial emosional, aspek motorik, aspek bahasa dan aspek seni. Dalam melakukan stimulus perkembangan anak usia dini harus sesuai dengan prinsip bahwa belajar sambil bermain. Pada masa pandemi ini guru dituntut tetap menggunakan pola bermain dalam meningkatkan perkembangan anak. Dari hasil angket ditemukan bahwa kinerja guru dalam menganalisis teori bermain dalam pembelajaran masuk kategori sangat baik dalam penerapannya. Hasil penelitian oleh Diah menyimpulkan bahwa bahwa $86 \%$ peserta menilai bahwa materi yang 
diberikan oleh guru, tentang "Program Bermain Bersama Anak selama masa Pandemi Covid 19" sangat sesuai dengan harapan mereka[9].

Kinerja guru PAUD dalam merancang kegiatan pengembangan AUD berdasar kurikulum juga masuk dalam kategori sangat baik. Pelaksanaan pembelajaran yang dilakukan di rumah tentu harus dirancang sesuai kurikulum yang telah disiapkan. Sehingga pelaksanaan pembelajaran tetap dapat dilakukan dengan model visit home dengan berbagai jenis kegiatan yang bisa menarik perhatian anak. Permainan Playdough ini bisa menjadi alternatif guru dan orangtua dalam mengisi proses pembejaran pada masa pandemic covid-19. Bermaian playdough mampu meningkatkan perkembangan kecerdasan visual spasial anak usia dini pada masa pandemic covid-19. Home visit bisa menjadi alternatif untuk pendidik PAUD bisa menjalankan proses pembelajaran di rumah peserta didik[10]. Selain merancang proses pembelajaran sesuai dengan kurikulum, guru juga harus mampu menyelenggarakan kegiatan pengembangan yang mendidikanak usia dini. Hasil penelitian yang dilakukan oleh Nahdi bahwa Penerapan proses belajar di rumah ini memberikan sebuah gambaran jelas terkait sejauh mana penerapan pembelajaran di kala pandemic covid-19 ini berlangsung. Selain itu, proses belajar di rumah bagi anak tidak menghambat produktivitas anak dalam mengembangkan berbagai aspeknya. Ada penugasan yang diberikan dalam pengerjaan Lembar Kerja Anak, Memberikan kebebasan kepada orang tua untuk memonitoring dan memberikan aktivitas sendiri kepada anak, serta melalui home visit pihak sekolah mampu memonitoring perkembangan anak dengan baik[11].

Dalam penerapan pembelajaran daring kinerja guru PAUD harus dituntut untuk dapat mengusai teknologi dan informasi. Hasil penelitian ini menemukan bahwa kinerja guru PAUD dalam memanfaatkan TIK untuk kepentingan penyelenggaraan pengembangan yang mendidik masuk dalam kategori sangat baik. Penguasaan TIK ini dapat membantu guru dalam proses pembelajaran jarak jauh yang dilakukan oleh guru dan peserta didik. Pelaksanaan Belajar dari Rumah (BDR) untuk anak usia dini dilakukan dengan berbagai metode baik secara daring (dengan jarinagn) maupun luring (tanpa jaringan). Namun berbagai permasalahan muncul pada saat pelaksanaan kegiatan belajar dari rumah. Hasil penelitian Nurdin menyimpulkan bahwa Masih banyak pendidik PAUD yang belum mahir menggunakan aplikasi pembelajaran online. Metode pembelajaran yang digunakan masih dominan pemberian tugas kepada peserta didik[12]. Hasil penelitian Aris menyimpulkan bahwa proses transformasi nilai pendidikan Islam anak dilakukan oleh guru bersama orang tua melalui komunikasi online (whatsapp) mengalami hambatan, tidak seperti aktifitas tatap muka[13]. Adapun beberapa upaya yang dapat mengoptimalkan kegiatan Belajar dari Rumah (BDR) untuk anak usia dini dimasa pandemi seperti saat ini diantaranya adalah kemampuan pendidik (guru PAUD) dalam menggunakan berbagai media untuk mendukung kegiatan Belajar dari rumah (BDR), serta dukungan dari orang tua terhadap pelaksanaan kegiatan Belajar dari rumah (BDR)[14]. Kemajuan teknologi informasi yang sudah sangat maju saat ini, internet bisa menghubungkan siswa dengan guru melalui laman e-learning, whatsapp group, google class,google doc atau google form, zoom[15]. 
Penilaian dan pelaporan perkembangan anak sangat penting dilakukan oleh guru, karena melalui penilaian dan pelaporan dapat mengetahui sejauhmana anak sudah mencapai perkembangan yang harus dimilikinya. Penilaian dan pelaporan perkembangan dilakukan guru sejak anak tiba di sekolah sampai anak pulang ke rumah. Menurut Nugraha memandang bahwa penilaian adalah mengumpulkan, menyeleksi, dan mengartikan informasi dalam mengambil suatu keputusan. Dalam Permendikbud No. 146 Tahun 2014 dijelaskan bahwa penilaian adalah proses pengolahan informasi, pengumpulan kemampuan untuk mengukur tingkat pencapaian kegiatan proses belajar anak[16]. Guru melakukan penilaian perkembangan dengan melakukan pengamatan/observasi terhadap tingkah laku, ucapan, mimik wajah, dan kegiatan selama di sekolah dengan menggunakan berbagai macam teknik penilaian. Namun kendala saat pandemi covid 19, pembelajaran dilakukan dari rumah sehingga guru mengalami kesulitan untuk melakukan penilaian dan pelaporan perkembangan anak. Menurut hasil penelitian yang dilakukan oleh Maryani menyimpulkan bahwa Perlunya kerjasama dengan pihak orang tua dengan melakukan komunikasi efektif berkaitan dengan kegiatan pembelajaran yang dilakaukan selama pembelajaran dari rumah karena pelaksana kegiatan adalah orang tua. Berikan penjelasan mengenai pentingnya memberikan stimulasi sejak dini dan melakukan laporan kegiatan anak kepada guru melalui artikel-artikel ataupun melalui komunikasi langsung. Kegiatan dapat berupa perencanaan yang telah dirancang dari lembaga ataupun kegiatan yang dilakukan bersama orang tua di rumah. Kegiatan yang diberikan lebih kepada pengembangan keterampilan hidup dan karakter anak. Pemberian kegiatan dapat dilakukan dengan memanfaatkan media online berupa whatshapp, facebook, zoom meeting, google meet, dengan membuat perencanaan pelaksanaannya ataupun membuat perencanaan kegiatan yang dapat diambil oleh orang tua ke lembaga dengan memperhatikan protokol kesehatan[17].

Secara keseluruhan skor rata-rata yang diperoleh untuk mengetahui kinerja mengajar Guru PAUD di Kota Serang Pada Masa Pandemi Covid 19 adalah 4.34. Hal ini berarti bahwa dalam masa pandemi covid 19 sekalipun kinerja mengajar guru PAUD di Kota Serang termasuk dalam kategori sangat baik. Dalam penelitian ini dapat dimaknai juga bahwa Guru PAUD memiliki kinerja mengajar yang sangat baik, pembuktian terhadap kinerja mengajar guru yang sangat baik ini dapat dilihat dari jawaban yang diisi oleh responden pada item pertanyaan yang di sampaikan dalam kuesioner yang disebar tersebut.

\section{KESIMPULAN}

Secara umum, kinerja mengajar guru PAUD di kota serang pada masa pandemi covid 19 berada pada kategori sangat tinggi, dengan rata-rata skor 4,34. Skor tersebut jika di konsultasikan dengan table WMS (Weight Mean Skor), maka Kinerja mengajar guru PAUD di kota serang pada masa pandemic covid 19 sangat baik, para guru berupaya memberikan pelayanan yang prima kepada peserta didik dengan mempertahankan atau bahkan meningkatkan kompetensi mereka dalam upaya menyelenggarakan pendidikan 
yang bermutu. Optimalisasi kinerja guru dilihat dari bagaimana guru mempersiapkan diri baik sarana maupun prasarana dalam menyelenggarakan pembelajaran dari rumah tersebut.

\section{PENGHARGAAN}

Terima kasih penulis ucapkan kepada seluruh guru PAUD se Kota Serang dan semua pihak yang telah membantu pelaksanaan penelitian dan penulisan artikel ini. Tidak lupa ucapan terima kasih kepada editor dan reviewer Jurnal Murhum yang sudah memberikan kesempatan sehingga jurnal bisa untuk diterbitkan

\section{REFERENSI}

[1] Pemprov Banten, "WFH Kembali Diperpanjang, Gubernur: ASN di Wilayah PSBB Agar Ikuti Aturan," https://www.bantenprov.go.id/, 2020. [Online]. Available: https://www.bantenprov.go.id/pressrealease/wfh-kembali-diperpanjang-gubernur-asndi-wilayah-psbb-agar-ikuti-aturan.

[2] Supardi, Kinerja Guru. Jakarta: Raja Grafindo Persada, 2013.

[3] A. T. Pudyastuti and C. A. Budiningsih, "Efektivitas Pembelajaran E-Learning pada Guru PAUD Selama Pandemic Covid-19," J. Obs. J. Pendidik. Anak Usia Dini, vol. 5, no. 2, pp. 1667-1675, 2021.

[4] Mustakim, "Efektivitas Pembelajaran Daring Menggunakan Media Online Selama Pandemi Covid-19 Pada Mata Pelajaran Matematika the Effectiveness of E-Learning Using Online Media During the Covid-19 Pandemic in Mathematics," Al asma J. Islam. Educ., vol. 2, no. 1, pp. 1-12, 2020.

[5] L. Anhusadar, "Persepsi Mahasiswa PIAUD terhadap Kuliah Online di Masa Pandemi Covid 19," KINDERGARTEN J. Islam. Early Child. Educ., vol. 3, no. 1, p. 44, Apr. 2020.

[6] R. Tanjung, "Peran Orangtua dalam Pendidikan Anak Usia Dini di Masa Pandemi Covid-19," Murhum J. Pendidik. Anak Usia Dini, vol. 1, no. 2, pp. 64-73, 2020.

[7] A. N. Fadlilah, "Strategi Menghidupkan Motivasi Belajar Anak Usia Dini Selama Pandemi COVID-19 melalui Publikasi," J. Obs. J. Pendidik. Anak Usia Dini, vol. 5, no. 1, p. 373, Jun. 2020.

[8] L. Anhusadar, "Evaluasi Pelaksanaan Standar Produk Hasil Belajar pada Satuan Pendidikan Anak Usia Dini," Al-TA'DIB J. Kaji. Ilmu Kependidikan, vol. 13, no. 1, p. 34, Jun. 2020.

[9] D. A. Sari, T. Astari, I. Yulianingsih, and N. N. Cahyanti, "Evaluasi Seminar Nasional Online , Program Bermain Bersama Anak Selama Masa Pandemi Covid 19," Murhum J. Pendidik. Anak Usia Dini, vol. 1, no. 1, pp. 65-78, 2020.

[10] N. Widiastita and L. Anhusadar, "Bermain Playdough dalam Meningkatkan Kecerdasan Visual-Spasial Melalui Home Visit di Tengah Pandemi Covid-19," Murhum J. Pendidik. Anak Usia Dini, vol. 1, no. 2, pp. 50-63, 2020.

[11] K. Nahdi, S. Ramdhani, R. R. Yuliatin, and Y. A. Hadi, "Implementasi Pembelajaran pada Masa Lockdown bagi Lembaga PAUD di Kabupaten Lombok Timur," J. Obs. J. Pendidik. Anak Usia Dini, vol. 5, no. 1, p. 177, 2020.

[12] N. Nurdin and L. Anhusadar, "Efektivitas Pembelajaran Online Pendidik PAUD di Tengah Pandemi Covid 19," J. Obs. J. Pendidik. Anak Usia Dini, vol. 5, no. 1, p. 686, Aug. 2020. 
[13] J. Aris Try Andreas Putra, Sufiani, "Transformasi Nilai Pendidikan Islam Anak di PAUD Sultan Qaimuddin Kendari Pada Masa Pandemi Covid 19," Murhum J. Pendidik. Anak Usia Dini, vol. 1, no. 1, 2020.

[14] A. Fujiawati, Fuja Siti; Raharja, Reza Mauldy; Iman, "Pemanfaatan Teknologi Pendidikan di Masa Pandemi Covid-19," Pros. Semin. Nas. Pendidik. FKIP UNTIRTA, vol. 3, no. 1, pp. 120-126, 2020.

[15] N. K. S. Astini, "Pemanfaatan Teknologi Informasi dalam Pembelajaran Tingkat Sekolah Dasar pada Masa Pandemi Covid-19," J. Lemb. Penjaminan Mutu STKIP Agama Hindu Amlapura, vol. 11, no. 2, pp. 13-25, 2020.

[16] K. Khadijah and N. Amelia, "Asesmen Perkembangan Kognitif Anak Usia 5-6 Tahun," Al-Athfaal J. Ilm. Pendidik. Anak Usia Dini, vol. 3, no. 1, pp. 69-82, Jun. 2020.

[17] K. Maryani, "Penilaian dan Pelaporan Perkembangan Anak Saat Pembelajaran di Rumah di Masa Pendemi Covid-19," Murhum J. Pendidik. Anak Usia Dini, vol. 1, no. 1, pp. 41-52, 2020. 